\title{
A Review of Performance Bonding in Forest Policy Settings
}

\author{
Olli-Pekka Kuusela $^{1}$ - Gregory S. Amacher ${ }^{2}$
}

Published online: 17 August 2016

(C) Springer International Publishing AG 2016

\begin{abstract}
Forest policies have typically relied on prescriptive standards to mitigate various nonpoint negative externalities, whereas more recent approaches have focused on the use of incentive-based policies, such as payments for environmental services (PES), to encourage activities associated with positive externalities. We provide a general review on the current state of knowledge concerning prescriptive standards and incentive-based policies in the context of nonpoint and point source externalities that are typical in industrial and nonindustrial forestry. Our specific focus is on reviewing and assessing the current and future applications of performance bonding in forest policy. We argue that bonds can be viewed either as an enforcement mechanism to achieve compliance with standards, or alternatively, as a deposit-refund instrument that imposes a tax on harmful activities while subsidizing beneficial ones in the form of a refund. Four forest policy settings are considered: best management practices (BMP) for protecting the integrity of water resources, reduced impact logging (RIL) standards in industrial concessions, fire-fuel mitigation in wildland-urban interface (WUI), and carbon sequestration in standing forests and soils. Unique challenges that the
\end{abstract}

This article is part of the Topical Collection on Forest Policy, Economics, and Social Research

Olli-Pekka Kuusela

olli-pekka.kuusela@oregonstate.edu

Gregory S. Amacher

gamacher@vt.edu

1 Department of Forest Engineering, Resources and Management, Oregon State University, 263 Peavy Hall, Corvallis, OR 97331, USA

2 Department of Forest Resources and Environmental Conservation, Virginia Tech, 304 D. Cheatham Hall, Blacksburg, VA 24060, USA successful design of performance bonding present are used as motivation for future research.

Keywords Performance bonds $\cdot$ Deposit-refund $\cdot$ Best management practices (BMP) · Reduced impact logging (RIL) · Concession management · Forest fire risk · Wildland-urban interface (WUI) · Forest carbon · Nonpoint source

\section{Introduction}

Various positive and negative environmental externalities, or market inefficiencies, are frequently associated with standard logging and forest management practices. These include landowners' adjacency impacts to neighboring stands and provision of nonmarket and environmental services from standing forests that the society values but that are un-priced by the market (e.g., [1, 2]). There exists now a rich set of policy instruments aimed at encouraging the socially best production of these environmental services, or inducing reductions in socially harmful activities. Typical examples include costsharing subsidies, harvest permitting, charges and taxes, technology and management standards, as well as more recently introduced market-based incentives such as payments for environmental services (PES), mitigation banking, and carbon offsetting. As competing demands for forestland intensify, so does the demand for cost-effective planning tools and policy instruments. Policies are not, however, created equal and the choice between different options comes with tradeoffs in terms of efficiency, cost-effectiveness, and the cost of enforcement [3].

Performance bonding is an enforcement mechanism that has been widely used for different purposes in the context of forest management and logging contracting. In their simplest 
form, performance bonds are constructed to enforce contract rules and standards, bolster commitment between contracting parties, and provide insurance against noncompliance. Alternatively, bonding can be viewed as a deposit-refund scheme that acts as a mechanism to encourage socially beneficial actions. We contend that both of the above approaches to bonding — enforcement and incentive-based-have promising new uses in future forest policy design given the typical monitoring and enforcement challenges found in forestry. These include the nonpoint nature of socially harmful (beneficial) impacts of forest management activities on industrial and nonindustrial lands, and vast spatial scales that render monitoring of activities costly and impractical in many circumstances. Inherent stochasticity in natural processes, moreover, complicates the measurement of the severity of externality effects, and even locating the exact source for the externality in question can be problematic (e.g., [4-6]).

A review of the potential of bonding mechanisms that distinguishes between controlling point and nonpoint source forest externalities has not yet been undertaken in the forest economics literature, despite the growing importance of bonding to policy makers. We critically review and assess the uses and applicability of performance bonding in enforcing and encouraging changes in forest management and harvesting practices. We compare bonding mechanisms against other policies and focus on four potential areas of application for bonds: best management practices (BMP) in forestry operations, reduced impact logging (RIL) in tropical concessions, mitigation of wildfire risks in wildlandurban interface (WUI), and carbon sequestration services provided by forest biomass and soils. We keep our analysis for this paper at the discussion level but point the reader to more rigorous and mathematical treatments of the principles discussed and reviewed here.

Incentive- and price-based policy instruments have been repeatedly championed as an alternative to traditional command-and-control policies such as pollution control and technology standards. Typical incentive-based approaches have included taxes, charges, and subsidies, and more recently, market-based policies such as tradable permits [7]. Performance bonding is an example of an instrument that can be used to enforce compliance with stipulated standards, or alternatively, it can be used as an incentive-based mechanism. A prominent example of the latter is the already common recycling programs with deposit-refund schemes, which essentially work as a combination of a tax and subsidy payment [8]. The deposit is the tax component, whereas the subsidy is received after the appropriate reclamation or recycling activities have taken place [3]. As we will argue here, performance bonding is a combination of command and control and price regulation and as such, can be uniquely tailored to the regulatory objectives in forestry.
The next section provides a brief overview of the nature of typical forest externalities emanating from point and nonpoint sources, and a description of the types of regulatory challenges found in forestry. The third section then reviews common forest policy instruments and draws distinctions between standards and incentive-based policy approaches. The fourth section focuses on the application of bonds in forest policies using four case examples. Finally, we offer our conclusions in the last section.

\section{Sources of Externalities in Forestry}

An externality occurs when the owner, or a user, of a resource does not incur (enjoy) all the opportunity costs (benefits) associated with owning and using the resource [9]. In practice, this means that landowners or operators may not account for all the implications of their actions to their neighboring stands, nearby communities, or to the society at large when deciding on the use and extraction of local forest values. The reason behind the neglect can be either due to missing markets for environmental services and amenities, or because of the public good nature of the amenities in question. In the latter case, even the presence of a market may not solve the problem of under-provision, since the possibility to free ride constrains the potential income that can be generated from producing public goods on forest lands [10]. Therefore, one of the goals of forest policy is to mitigate these externalities, provided that the cost of regulation does not exceed the expected benefits [11]. The regulator typically focuses on both the timing and intensity of felling activities, and the type of management activities undertaken during and between the stand establishment and the final harvest.

Forest externalities exhibit both temporal and spatial features [12]. Carbon sequestration services provided by growing trees is an example of an intertemporal positive externality, whereas watershed protection and wildfire risk mitigation (fuel reduction) are examples of positive spatial externalities that may also exhibit an intertemporal component [13]. In these cases, missing markets and the under-provision of beneficial activities are caused by a variety of reasons. Spatial externalities can be hard to fully internalize without a policy intervention simply because of the prohibitive cost of arranging negotiations between multiple landowners and the large number of other affected parties [14, 15]. Free riding incentives among adjacent landowners lead to under-provision of public goods across space, such as taking actions to reduce hazardous fuels [16]. In the case of intertemporal externalities, negotiations may simply not be feasible because all the beneficiaries are yet to be born, or alternatively, the discount rates applied by private decision makers do not align with the social discount rate - there are many other transaction costs limiting these types of negotiations as well. Designing efficient and cost- 
effective policies to mitigate spatial and intertemporal externalities is a well-known policy challenge, and solving it may require a mix of complementary instruments [17].

Externalities in forestry and in agriculture share some common features, especially the difficulties associated with nonpoint sources of pollution [6]. Nonpoint pollution means that is difficult, or exceedingly costly, to determine the exact source of the externality since there is no single identifiable emitting source as pollution from multiple small sources gets aggregated before entering a receptor. For example, increased turbidity may be caused by multiple separate harvesting operations occurring at different locations in the vicinity of the same water body, and while the arrival of wildfires is a random event, their severity may depend on the conditions of various neighboring stands and the configuration of the landscape as a whole. There are also many examples of point source externalities in forestry. The impact of management practices in a specific forest land may directly affect the quality and quantity of watershed services for nearby communities, hence enabling a clear identification and targeting of the source. Another example of a clearly identifiable externality is the unsustainable logging practices adopted by a concession harvester on a particular site. However, even when the externality has an identifiable point source, the cost of enforcement with numerous sources and vast spatial scales are challenges that demand well-designed, targeted, and cost-effective monitoring and enforcement strategies [18].

Success in enforcing policies and monitoring compliance depend on the quality of the enforcement institutions, their budgetary limitations, and on the physical nature of the enforcement environment $[19,20]$. At a more conceptual level, there are two variables that determine the boundaries and limitations of forest policy design. The first one relates to the observability of actions taken by landowners and loggers. Here, the enforcement challenge is caused by vast spatial scales and limited resources, with the implication that the regulator has to mainly rely on the final inspection (or self-reporting) to verify that the agents have complied with the laws and regulations. The second is the considerable degree of stochasticity in the indicators that are used to assess either the level of compliance or the severity of the externality [21]. For example, natural variability in stream temperatures can make it difficult to determine the impact of nearby logging operations on adjacent water bodies $[6,22]$. The smaller the natural variability in stream conditions, the easier it is to establish a causal connection from activities on a specific land tract to changes in stream conditions. However, even a signal that is accurately describing the conditions of a particular receptor may not be enough to effectively enforce the compliance of individual sources, especially in cases where there are multiple potential polluters and no clear assignment of individual liability.

\section{Forest Policies and Regulations}

\section{Prescriptive Standards in Forestry}

There are broadly speaking two types of prescriptive standards that differ in their emphasis of targeting either management outcomes or management actions (choices). The first one is called a performance standard, and the second one a technology (process/design) standard [23]. Performance standards typically regulate the flow of an externality causing pollution such as the nutrient load entering a water body at a given time and in a given location. This means that there is a clearly identifiable source for emissions and the regulator monitors the "end-of-pipe" discharges. In the case of nonpoint source pollution, the use of performance standards is frequently not feasible. For example, when dealing with sediment discharges from multiple harvesting operations, it might not be possible to identify and measure the exact amount of runoff caused by a specific source [24]. Similarly, the leakage of pesticides and nutrients to water bodies as a result of forest management activities is a nonpoint source pollution [25]. In these cases, the regulator typically targets the application of chemicals and fertilizers instead of the flow of pollution, or mandates the use of technology standards such as riparian buffer zones [26].

In the case of nonpoint pollution, the regulator can also use some predefined indicator or a proxy variable for the overall externality effect to target the performance standard. These are called ambient standards, and they typically dictate the allowed concentration of pollutants in the environment per unit of time, such as the level of water turbidity, dissolved oxygen present in the water, or particulate matter released from prescribed burns that affects the air quality [27]. Protecting Cold Water Standards (PCWS) is another example of an ambient-based standard [28]. PCWS regulates humancaused maximum increases in stream temperatures using a natural baseline as a point of reference. In this case, heat energy is considered as a form of pollution that harms spawning and migration in cold-water fisheries [22]. Finally, a requirement for sustainability in logging and land management practices at the landscape level can also be thought of as an ambient-based standard. An indicator for compliance in these cases could be, for example, habitat suitability or biodiversity indices that track the habitat conditions for wildlife and endangered species, a scenic beauty index that attempts to measure the recreational values provided by the forests, or other economic indicators that measure the long-term sustainability of land management practices [29-32].

Compliance with ambient standards can be measured expost of the regulated activity, with penalties for noncompliance assessed based on the information provided by the ambient indicators. Ambient standards are, however, problematic to apply when natural variability in the chosen indicators render the information content of measurements less useful, thus 
making it difficult to verify actual compliance [26]. Even when the signal is deterministic, the application of ambient standards with nonpoint pollution is not necessarily attractive from the legal or political standpoint, since their use may necessitate the assignment of joint liability for potential environmental damages, as there are multiple sources that together, or individually, are causing the damage [3].

Technology (process/design) standards are another common approach to environmental regulation in forestry. For example, various best management practices (BMP's) have been developed and applied to reduce the negative environmental impacts stemming from logging operations [33]. BMP's were originally designed to mitigate the negative impacts from farming and livestock production on water quality, but they have now come to represent a broad set of measures targeting a range of negative impacts from various land uses on water bodies [34, 35]. There are also various types of logging restrictions that can be categorized as technological standards. Timber concession contracts on public lands frequently mandate the use of predefined felling cycles, and they typically restrict the annual allowable cuts and dictate diameter limits for harvesting [36-38]. In some jurisdictions, the allowable area cut per operation is restricted, thus establishing a legal upper limit for the size of the final harvest [7, 39]. Regulations may also specify what type of tree species have to be replanted for designated areas, and the number of seedlings that must survive per area unit for the landowner to be deemed compliant with reforestation standards.

The main perceived advantage of technology standards is that they, at least in principle, provide more certainty over the control of the externality causing activities. Performance and ambient standards, on the other hand, enable some flexibility over how to achieve compliance with given policy targets, but this can increase risks over the actual outcome since it is possible that the chosen actions are not successful in achieving the specified targets. The benefit of allowing flexibility is to improve the cost efficiency of regulation since landowners and operators are free to choose and experiment with the most cost efficient approaches given their particular circumstances. Correspondingly, the main disadvantage of technological standards is that they restrain the impetus to experiment with new technologies and practices that could achieve the same environmental quality with lower cost [40, 41].

Enforcement of standards entails a constant monitoring of activities and imposition of penalties when noncompliance is detected. Sanctions come typically in the form of ex-post fines, penalties, or forfeiture of the operation permit. Performance bonds can also be used to enforce standards, and we discuss their applications in more detail in the following section. Enforcement success fundamentally depends on the regulator's effort and ability to detect and penalize violators with a credible threat $[19,42]$. The presence of incomplete information, however, challenges the design of an effective policy and the detection of the level of compliance $[43,44]$. Enforcement effectiveness is also influenced by the quality of institutions, pressure from peers and other stakeholders, as well as by the culture of abiding to the rules [18, 45-47]. Many of the above elements differ between countries and jurisdictions, making the effectiveness of command and control regulation dependent on the specific location and the local institutions.

Given these challenges, it is not always straightforward to determine which type of a standard should be preferred in terms of having the lowest regulatory costs (monitoring and enforcement). In principle, compliance with technology standards should be easy to verify, but in practice, it may require considerable effort to ensure that a harvester has installed and is using all the required technologies and activities. Accurate and uncontroversial ambient indicators would certainty alleviate these problems, as the regulator would be able to clearly detect the presence of noncompliance. This said, when regulating nonpoint source externalities and given the typical stochasticity in ambient indicators, relying on technology standards and the final inspection may be the only feasible approaches. We argue in the next section that, under these types of regulatory circumstances, the bond instrument possesses many attractive qualities for the regulator and the landowners.

\section{Incentive-Based Policies}

Traditional incentive-based (IB) policies include charges (taxes) that create a disincentive for socially harmful activities, and cost-sharing mechanisms (subsidies) that encourage activities that are undersupplied from the society's perspective. The general idea behind IB policies is to use the price system to change the relevant opportunity costs enough to create an incentive for the resource owner to adopt socially beneficial actions. The owners then adopt new management approaches and regimes voluntarily to receive outside payments as a reward for actions or as a compensation for costs, or alternatively, in the case of taxes and charges, they change their behavior to reduce the tax payments for which they are liable. For example, PES is intended to create new markets where landowners can profit from changing their forest plans to specifically incorporate considerations for various ecosystem values [48-50]. In other places, PES encourages reforestation and afforestation activities and other actions that reduce the risk of future forest degradation and deforestation by changing the relevant opportunity costs faced by landowners, land managers, or forest dependent communities [51-53]. Bonding mechanisms can also be designed to emulate IB policies. These typically take the form of deposit-refund schemes. The advantage of deposit-refund schemes is that they can 
provide the necessary funds to run the reclamation and recycling activities, and they can also provide some degree of insurance to compensate for environmental or economic damages when they do occur.

As the case with performance standards, the enforcement complexities related to nonpoint pollution and the stochasticity of ambient indicators can reduce the range of opportunities for the use of IB policies. In order for the landowner to receive a payment, or to be charged for something, the regulator has to be able to observe some metric related to the externality effect, whether it is the stock of carbon sequestered, smoke from prescribed burnings, the amount of soil runoff released to water bodies, or changes in stream temperatures. Recent developments in remote sensing have the potential of alleviating the extent of these problems in the future, thus creating new opportunities for the application of IB policies [54].

The main advantage of IB instruments is that they are more conducive to enabling a cost efficient compliance outcome as landowners, and harvesters can choose the best measures that achieve the prescribed environmental quality targets using their private and more detailed knowledge of costs of different technology and management options. IB instruments also encourage innovation in cost-cutting technologies and in new management practices, which does not typically occur under technology standards, as there is no need to experiment with alternative technologies $[55,56]$. It is also possible to use revenues from environmental charges to reduce other distortionary taxes - this possibility has been termed the "double dividend" in the literature [57]. The downside of subsidies is that they can make the receiving industries more profitable and therefore attract more firms to enter the market. They are obviously also a burden to public funds [3]. Nevertheless, the use of subsidies frequently remains as the only politically viable option, especially when targeting private landowners or forest dependent households in rural communities.

\section{Performance Bonding in Forestry}

Performance bonding is a case where a forest harvester or a landowner submits a bond that is paid back upon observed compliance with a required standard, such as BMP's, or after successful completion of any other requirement stipulated in a harvesting contract or in forest practice acts. Alternatively, it is also possible to tie the release of the bond to verified compliance with legally mandated ambient quality standards, or with some other performance related metric. The basic logic of bonding mechanisms is easy to understand, and not surprisingly, it has found many uses in different regulatory settings [58]. Performance deposits are widely used in private timber contracting to enforce compliance with a variety of standards that require the deployment of good management practices on the part of the harvester. ${ }^{1}$ Some other well-known examples include refundable deposit schemes in the beverage industry, and performance bonds in mine land reclamation in the USA and Australia [3, 59-61]. ${ }^{2}$

Bonds have also been studied in the general economics and compliance literature [66-68]. One of the most critical decisions in the implementation of bonding schemes is the setting of the initial bond payment, and there are contrasting views on this issue. Costanza and Perrings [69] propose that the bond payment should be high enough to compensate for the incidence of any environmental damages that may occur, whereas Shogren et al. [70] favor the approach where the bond is set to an adequate level that is just enough to induce compliance. The first approach views bonds as a form of insurance that indemnifies the public against all potential environmental damages, whereas the second approach is more in line with the enforcement approach [56]. Balancing between these two viewpoints has tradeoffs. Too high of a bond payment may create an excessive burden for the logging operators and landowners, which may in turn reduce the incentives for participating in regulated activities, and potentially encouraging participation in illegal ones. Too low of a bond payment, on the other hand, might not provide a strong enough incentive for compliance with the specified standards, or for the adoption of alternative management plans, while leaving the landowner or the society with little funds to compensate for potential losses caused by residual stand damages or other damages to environmental values that in some cases take time to materialize.

The key distinction for our purposes is between using the bond instrument to enforce compliance with legally mandated standards and contract rules, and using it for creating incentives for taking actions that mitigate the causes of negative externalities, or encourage actions associated with positive externalities. In other words, bonds can be used to target both performance criteria and management outcomes [38, 71]. When bonds are used to enforce compliance with technology or performance standards - such as riparian buffer width or prescribed logging techniques and technologies - they take the form of enforcement mechanism, with the added benefit of providing insurance against noncompliance. Alternatively, bonding mechanisms can be designed to work more like an IB policy that is designed to alter the opportunity costs associated with socially harmful actions. This approach resembles a tax and subsidy scheme where the landowner first pays the tax regardless of the final outcome and then receives the subsidy in the form of the bond repayment, given that such actions are taken that lead

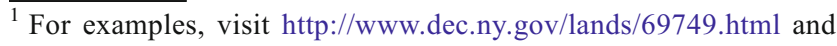
http://www.ncforestry.org/landowners/.

${ }^{2}$ In the mining example, bonds have been used to enforce compliance with restoration and reclamation rules in surface and below ground mining industries, with the applications in shale gas extraction being the latest example [62-65].
} 
to a measurable improvement in the final outcome when compared to some predefined reference level [72-75].

As we have discussed earlier, forestry externalities exhibit both nonpoint and point source characteristics, and both legally mandated standards and incentive-based policies have been applied in the past to influence management choices and thus to change outcomes. Vast spatial scales and stochasticity in performance and ambient metrics, however, render the enforcement of standards in both point and nonpoint case challenge. Performance bonding has therefore the potential of providing a dual benefit as a part of the solution to the enforcement problem. First, bonding schemes effectively transfer the burden of evidence for compliance over to the harvester, while concurrently retaining necessary funds for possible cleanup and damage control activities in cases of noncompliance [58, 76]. This has the potential of reducing the regulator's enforcement burden by leveraging the effectiveness of the final inspection and verification phase. Second, bonds are useful in situations where there is significant uncertainty about the compliance outcome, or where there are risks associated with the conduct of operations, and the assumption is that the bond holder wishes to retain some insurance, and does not necessarily trust the litigation process to provide timely funds for compensation (or the litigation process is prohibitively costly). For example, performance deposits provide insurance against risks related to lost value through stand damages or environmental damages that may require a salvage operation.

In the case of an IB approach, bonds have also the potential of offering a dual benefit. First, the tax-subsidy nature of the bond scheme targets management actions that generate negative externalities with the tax payment, while encouraging the generation of positive externalities with the subsidy, but without the burden on public funds. An example for this type of an application is the control of externalities associated with forest carbon. A carbon tax on the basis of released carbon content could be levied at the time of the harvest, whereas an annual subsidy for carbon sequestration would reward landowners for actions that accumulate forest carbon over time [77]. Second, bond payments generate a pool of funds that the regulator can use to mitigate the costly impacts from damages. For example, when applied to the IB approach of controlling hazardous fuels in overstocked stands, the pool of bond payments can offer a possible source of funds for public safety measures such as fire suppression and the prevention of negative health impacts from smoke.

To accommodate the wide range of circumstances found in different settings relevant to bond schemes, we investigate the use of bond instruments in four different regulation scenarios to highlight the similarities and differences facing both the regulators and the regulated entities (Table 1). We have selected these cases to highlight the use of bonds as an IB instrument or as an enforcement mechanism in applications where the type of the externality can be either point or nonpoint.
Table 1 Four policy scenarios where the externality can be either point or nonpoint in nature and the bonding instrument can represent either an enforcement mechanism or an incentive-based policy approach

\begin{tabular}{lll}
\hline & $\begin{array}{l}\text { Enforcement of } \\
\text { standards }\end{array}$ & $\begin{array}{l}\text { Incentive-based } \\
\text { policies }\end{array}$ \\
\hline $\begin{array}{l}\text { Nonpoint source } \\
\text { externality }\end{array}$ & Water quality BMP's & Wildfire risk \\
$\begin{array}{l}\text { Point source externality } \\
\text { Reduced impact } \\
\text { logging (RIL) }\end{array}$ & Carbon sequestration \\
\hline
\end{tabular}

\section{Water Quality BMP's}

Historical forest management practices based on improper or over-harvesting of streamside riparian vegetation have sometimes resulted in negative impacts on aquatic ecosystem health and source water quality for downstream users due to increased erosion and sedimentation and stream temperatures. This is an example of a non-point externality. In such cases, the typical regulatory approach has been to prescribe technology-based standards such as BMPs. The use of BMPs is mandatory in some jurisdictions, while in others, their adoption is encouraged but nevertheless voluntary. Forest Practices Acts (FPA) legislated in western and northeastern US states require a fixed set of BMPs implemented during logging operations, whereas southeastern states allow landowners and harvesters to select a combination of approved practices to achieve a specific water quality standard [78]. Thus, the southeastern states apply ambient-based performance standards, whereas western and northeastern states rely more on the use of technological standards. In either case, a bond instrument can, in principle, be used to enforce compliance with the prescribed environmental standards.

The main difference between enforcing an ambient standard and a technological standard is in deciding the criteria that need to be satisfied before the bond can be released. Enforcement of a technology standard can be tied to the final inspection where it is possible, at least in principle, to accurately determine the level of compliance, whereas ambient indicators are more susceptible to the natural background variation that may lead to difficulties in assigning liability. Through careful design, these problems can be overcome, as we will suggest here using the case of enforcing stream temperature standards as an example. However, it could be the case that the use of ambient targeting is not feasible in all circumstances, for example, because it is not possible to define uncontroversial and accurate criteria for compliance. When this happens, bonds may have to be used to only target technology choices, such as fixed buffer width.

PCWS in Oregon is an example of an ambient-based water quality standard [79]. The criteria in PCWS set a limit of $0.3{ }^{\circ} \mathrm{C}$ for the allowed post-harvesting increase in stream temperatures in fish bearing water bodies when compared to natural reference temperatures that are typical to the area in 
question. When measurement instruments detect temperatures above the allowed threshold, the next step is to identify the exact source causing the temperature increase. A harvesting operation that has not installed the appropriate BMP's, such as fixed-width stream buffers, would be a potential suspect. ${ }^{3}$ But with multiple harvesters along the same stream system, identification of the exact source that caused the temperature increase can be challenging, as there is considerable variation in the natural background temperatures, especially in small streams, thus complicating accurate monitoring. The upside of ambient standards is that they potentially allow for flexibility in achieving compliance with the policy given that the landowners and operators face correct incentives. This would yield an improvement to the case where fixed-width buffers are universally applied to all harvesting sites regardless of their location vis-à-vis environmentally sensitive areas, even when the cost of compliance with fixed standards turns out to be costlier than the actual benefits received. Correct incentives would encourage efforts to experiment with variable width buffers and other technologies that yield the same environmental benefits but with lower costs. ${ }^{4}$ Coincidentally, there is now an increasing recognition of preferring more landscape oriented solutions that have the potential for better satisfying ambient targets [81, 82]. Abandoning fixed-width buffers can, however, create a higher risk over the ultimate ambient quality (e.g. turbidity, temperatures) in sensitive stream systems, which would certainly be a reason for concern for a riskaverse regulator.

One potential policy solution would be to introduce performance bonding and joint liability in combination with the use of ambient targets. Harvesters would be able to experiment with site-specific best practices, and the regulator would retain some insurance over the potential damages and also funds for restoration activities if the operator for some reason defaults on its contractual obligations. The bond payment itself would generate an incentive for harvesters to comply with the ambient target in a way that ensures the release of the bond. Joint liability would mean that all the operators along the same stream system would be held accountable for achieving the ambient target [26]. Introduction of such a liability scheme would certainly be challenging, but the benefit would be to encourage harvesters to share information and techniques to achieve the ambient targets with the least cost. However, there is also the possibility that, even when forest managers are given the latitude to experiment with different actions and

\footnotetext{
$\overline{3}$ The use of such "one-size-fit-for-all" prescriptive standards has generated heated debate, and some even question the scientific merit of using temperature deviations as a gauge for the extent of damages to cold-water fisheries [28].

${ }^{4}$ For example, Richardson et al. [80] argue that the practice of establishing site specific, fixed-width riparian buffers was born out of administrative expediency and not necessarily based on scientifically measured or verified principles.
}

techniques, they may still adhere to the standard procedures, such as fixed-width riparian buffer, simply because the level of uncertainty over the effectiveness of alternatives is high [80]. But, it is also likely that some operators emerge as leaders in developing new strategies and techniques, and more risk-averse operators would then follow their lead.

\section{Reduced Impact Logging}

Environmental and financial losses associated with poor execution of concession harvesting represent a stylized example of a point source externality. Challenges in sustainable management of tropical forest concessions are especially well known and covered in the literature [83, 84]. One critical step toward achieving improved long-term timber concession outcomes is the adoption of reduced impact logging (RIL) standards. These essentially fall under the rubric of technology standards. The main goal of RIL techniques is to reduce collateral stand damages and soil disturbances, and hence yield long-term benefits to the landowner and other stakeholders [85]. Putz et al. [86] define reduced impact logging as "intensively planned and carefully controlled timber harvesting conducted by trained workers in ways that minimize the deleterious impacts of logging", and the list of actions cover, among many other things, detailed mapping of concession area, compilation of tree inventory, improved planning and construction of roads, application of directional felling techniques, and increased efficiency of yarding operations.

While the adoption of RIL techniques can yield some financial benefits, evidence on the relative profitability of RIL over more conventional logging practices is mixed [84, 87, 88•]. Macpherson et al. [89] provide simulation-based evidence on the improved profitability from installing a RIL system, but note that loggers will most likely adopt only those components of RIL that directly improve profitability, while likely neglecting the parts that generate reductions in externalities. Moreover, the adoption of even partial RIL may be hindered by the fact that many logging companies employ few foresters and engineers needed for the installment and execution of RIL [86]. Therefore, it is very likely that additional policy incentives are needed to achieve better compliance with RIL standards.

The use of performance bonding in industrial forest concessions delivers the dual benefit of, first, providing an enforcement mechanism for achieving compliance with RIL standards, and secondly, establishing a pool of funds for the ex-post damage mitigation. The potential of bonds as an alternative, or as a complement, to harvesting royalties has been discussed at least since in Paris et al. [90], with some more recent examples found in $[71,91,92]$. Simulation-based studies, such as those found in Boscolo and Vincent [38] and Macpherson et al. [93•], suggest that performance bonds can be an effective instrument in ensuring compliance with RIL standards. While these results are promising, actual ground 
experiences are still lacking. In the 1990's, both Philippines and Malaysia experimented with the use of forest concession bonds, but these schemes were soon terminated as harvesters simply forfeited the bond without implementing the required actions that would have improved the long-term sustainability of concession harvesting. One reason behind these failures might have been simply a too low of a bond payment to ensure compliance [60, 94]. Consequently, Ruzicka [95] and Nasi et al. [96] argue that it is still too early to reject the use of performance bonding in tropical concessions, as their potential is yet to be properly tested and therefore warrant further experimentation.

One lesson from failed bond experiments is that, for a bond payment to be an effective instrument, it must account for the location specific variation in fixed and variable costs, the impact of value-based timber royalties, and the endogenous choices over harvesting intensities in each diameter class and tree species. These requirements naturally impose a challenge for the government attempting to ensure full compliance with concessions rules [97]. Since much of this information is also private and unknown to the policy maker, the design of an effective bond scheme can become an even more complex problem. One solution would be to use an auction mechanism to elicit more accurate information about the required size of the bond payment. However, the presence of capital constraints may still hinder the potential for designing a firstbest bond instrument, thus necessitating making compromises in policy targets.

\section{Forest Fuel Reduction}

A relatively new consideration in forest policy design is the proper alignment of incentives for fuel reduction and mitigation of fire risk in the wildland-urban interface (WUI). There, landowner decisions about forest structure and fuel reduction have important implications for the damage once fire arrives. It is not surprising that the WUI has become a central policy issue in the USA, where fire suppression is estimated to cost several billion dollars per year [98, 99]. Risk of wildfire and the inflicted damages caused by the arrival of these damaging events can be treated in the same way as a nonpoint source externality since their arrival is stochastic. Landowners can mitigate the severity of wildfires once they arrive by using thinning or prescribed fires to reduce fuel loads. Bonding mechanisms in the form of a deposit-refund scheme could be used, in the same way as we discussed with BMPs, to create an incentive for landowners to reduce spatial externalities by undertaking enough fire risk mitigation to be socially optimal.

Given the scale of ownership and numbers of nonindustrial private forest landowners in the WUI, the cost of fuel reduction can limit incentives for achieving anything close to a socially best level of fuels on forest land, and therefore to mitigate risk of fire spreading from one landowner to another across a landscape. As with BMPs for forest logging, fuel reduction regulations are largely command and control, or are based on cooperation that is required in WUI communities for landowners who reside there. As such, most of the recent attention of the literature has been on creating incentives for homeowners having houses in established forest communities to limit fuels on their properties. To a large extent, this literature has focused on cooperation mechanisms (or standards) as well as community wide fuel reduction targeting [100, 101]. The fuels considered in these programs are largely ornamental trees and brush around home sites, as well as restrictions on house structural characteristics. The cost of fuel reduction is therefore thought to be a function of nonmarket goods that are foregone by removing ornamental trees from a homeowner's property $[102,103,104 \cdot, 105] .^{5}$

In a more traditional forest management setting, where landowners establish and manage forests based on rotation age silviculture, fuel reduction has been studied as a removal of timber from production or an index of fuel reduction effort that negatively affects yield at harvesting times, with work considering these decisions in the context of adjacent landowners where fuel reduction effort benefits and causes spillovers as an externality imposed on neighboring forests. For the first examples of this problem, see [14, 102, 106]. In this respect, fuel reduction and risk mitigation have much in common with the best management practices discussed in the preceding section. In fact, the costs of fuel reduction affect landowner welfare in the same way as BMP restrictions do, in that fuel reduction represents a significant reduction to present value land rents. Thus, there is no expectation that landowners will have great incentives to undertake fuel removal on their own.

There is some literature that suggests empirically that forest landowners recognize the spatial relationships between fuels on neighboring property and fire risk on their land [107, 108]. Despite this, cooperation across space may not be as feasible in a more traditional forest management context. There would be obvious transaction costs of forest landowners coordinating their actions, not the least of which is the fact that absentee ownership often comprises nearly $30 \%$ of land ownership for nonindustrial private land in the USA (see [15]). The most common instrument in these situations to incentivize fuel reduction has therefore been more traditional cost-sharing programs (see [109]). Further, in the large literature that comprises forest policy design for nonindustrial forest landowners, the common first best instrument to control behavior has been either a carrot-stick type of policy, or a direct tax that internalizes costs of externalities characterizing forest management

\footnotetext{
$\overline{5}$ Butry and Donovan [102] study collective action, while Shafran [103] and Busby et al. [104•] consider strategic behavior between landowners as a Nash game.
} 
[110]. To a large extent, these policies have only been considered in the common externality problem where a private landowner disregards public goods amenities from unharvested forest stocks that matter to society (see [2], chapter 5 for a review of this literature).

One potential issue complicating bond choice in fire mitigation problems is the risk inherent in fire arriving, as well as the effectiveness of fuel treatment in reducing this risk. There is disagreement in the literature concerning the impact of fuel reduction on the probability of fire arrival in a stand and the expected damages once fire arrives. This assumption is part of a large portion of the literature on forest management and risk for natural disturbances. In this literature, it is often (but not always) assumed that damage to a stand once a fire arrives depends on the condition of the stand, although the probability of fire arriving does not depend on stand management decisions. This is clearly the case with many fire events that arrive in fronts and do not depend on a landowner's decisions in the past or what adjoining landowners have chosen, but the damage to the stand is definitely dependent on these decisions. A large body of literature supports this for natural events such as fires and weather shocks [109, 111-116].

There are at least two potential applications of performance bonding related to forest fire prevention policies. The first would be to require a bond deposit before commencement of prescribed burnings or other measurable and observable fuel reduction strategies such as thinning of a forest. This would generate an incentive for managers and landowners to undertake appropriate precautionary measures to prevent the spread of fire to adjacent properties. The second application is to design a deposit-refund scheme for landowners to penalize accumulation of hazardous fuels and reward those who commence fuel removals. These bond deposits can be furthermore spatially differentiated to capture the variation and severity of risks in the landscape. Once the landowners have taken actions to reduce fuels to levels that are deemed safe, the regulator would release the bond. These types of schemes could work especially well in the context of WUI since landowners would now have a stronger incentive to take actions to be eligible for the refund. The pool of bond payments would also generate additional funds to suppress catastrophic fires.

\section{Forest Carbon}

Our last policy example focuses on carbon sequestration services provided by trees and forest soils [117]. Landowners can influence the stock of carbon that is sequestered over time through management and harvesting plans, while more extensive changes in land use types (land conversion) carry permanent changes in potential carbon stocks [118-120]. Carbon sequestration is an example of point source positive externality and potentially amenable to incentive-based policy approaches like the ones we have been discussing. Release of carbon emissions from land management activities, harvesting, or wildfires are examples of negative externalities. A deposit-refund scheme could be developed where the landowner posts a deposit at the beginning of the rotation and gradually receives refunds back from the deposit fund by providing carbon sequestration services as the forest grows. The original deposit would essentially act as an effective tax on the negative externalities caused by the removal of trees, and the refund would act as a subsidy for sequestration services. Essentially, the basic principle of carbon deposit-refund scheme would follow the typical tax-subsidy policies that have been examined extensively in the literature [77, 121]. The presence of asymmetric information about the opportunity cost of carbon sequestration through landowner actions would potentially complicate the bond design and necessitate more variable payments for different landowner types [122].

\section{Concluding Remarks}

Forestry externalities exhibit both point and nonpoint characteristics together with diverse spatial and temporal manifestations. As a result, both standards - technology and ambient basedand incentive-based policies have been applied, with historically heavier emphasis on standards due to the prominence of nonpoint source externalities. We have reviewed the principles of forest policy instruments with a particular focus on current and potential future applications of performance bonding. Bonds can be used as an enforcement mechanism to achieve compliance with specified regulatory standards, or alternatively as depositrefund schemes which essentially tax harmful activities and subsidize beneficial ones. Potential benefits of bonding schemes are the insurance provided against noncompliance, potentially less resistance from the regulated entities than sole tax instruments, and if designed properly, cost-reducing innovations and experimentation by resource owners and managers through new techniques and management strategies.

Successful design of performance bonding schemes faces multiple and in many cases unique challenges, suggesting much scope for further study. These include the effects of private (and asymmetric) information on setting the correct initial bond payment, and risks of bond failures that undermine the effectiveness of these schemes. These risks include the failure to receive the bond repayment even when compliance is at a level that is sufficient to justify the release, or efforts by the regulated entities to legally challenge and reverse the confiscation of the bond even after verified noncompliance. Most of these concerns can be alleviated through careful contract design, third party verification, and by having an effective and independent judicial intermediation when disputes do occur. But in situations where these attributes are lacking or unattainable, as is the case with some tropical forests, a successful bonding scheme may be more difficult to implement. 
The presence of capital constraints on the part of forest landowners and harvesters also present another major challenge, and there is additionally a potential tendency among the regulated entities to exaggerate the costs associated with posting a bond. Too low of a bond payment can, however, lead to the inevitable noncompliance and confiscation of the bond, which can then be claimed as providing evidence against the effectiveness of the bonding mechanism itself. The above problems may not be as great in situations with repeated interactions, as reputational effects can become important between the bond payer and the regulator. But in less than ideal regulatory environments, reputational effects may not be important enough to change behavior, or reputational effects could be clouded through corruption in the government. Most of these issues go beyond bonding schemes, however, and work to the detriment of any policy, whether it is command and control or incentive-based.

\section{Compliance with Ethical Standards}

Conflict of Interest Drs Kuusela and Amacher declare no conflicts of interest.

Human and Animal Rights and Informed Consent This article does not contain any studies with human or animal subjects performed by the author.

\section{References}

Papers of particular interest, published recently, have been highlighted as:

- Of importance

1. Venn TJ, Calkin DE. Accommodating non-market values in evaluation of wildfire management in the United States: challenges and opportunities. Int J Wildland Fire. 2011;20(3):327-39.

2. Amacher GS, Ollikainen M, Koskela E. Economics of forest resources. Cambridge: Mit Press; 2009.

3. Sterner, T., Policy instruments for environmental and natural resource management. 2003: Resources for the Future.

4. Andréassian V. Waters and forests: from historical controversy to scientific debate. J Hydrol. 2004;291(1):1-27.

5. Brown AE, Zhang L, McMahon TA, Western AW, Vertessy RA. A review of paired catchment studies for determining changes in water yield resulting from alterations in vegetation. J Hydrol. 2005;310(1):28-61.

6. Loehle C, Wigley Jr TB, Lucier Jr A, Schilling E, Danehy RJ, Ice G. Toward improved water quality in forestry: opportunities and challenges in a changing regulatory environment. J For. 2014;112(1):41.

7. Cubbage F, Harou P, Sills E. Policy instruments to enhance multifunctional forest management. Forest Policy Econ. 2007;9(7): $833-51$.

8. Walls, M., Deposit-refund systems in practice and theory. Resources for the Future Discussion Paper, 2011(11-47).

9. Baumol, W.J. and W.E. Oates, The theory of environmental policy. 1988: Cambridge university press.

10. Montgomery, C.A. and M.S. Crandall, The economics of oldgrowth forests, in handbook of forest resource economics, S. Kant and J.R.R. Alavalapati, Editors. 2014, Routledge.
11. Coase, R.H., The problem of social cost. 1960: Springer.

12. Koskela E, Ollikainen M. Optimal private and public harvesting under spatial and temporal interdependence. For Sci. 2001;47(4): 484-96.

13. Montgomery, C.A., An agent and a consequence of land use change. The Oxford Handbook of Land Economics, 2014: p. 281.

14. Crowley CSL, Malik AS, Amacher GS, Haight RG. Adjacency externalities and forest fire prevention. Land Econ. 2009;85(1): $162-85$.

15. Vokoun M, Amacher GS, Sullivan J, Wear D. Examining incentives for adjacent non-industrial private forest landowners to cooperate. Forest Policy Econ. 2010;12(2):104-10.

16. Busby G, Albers HJ. Wildfire risk management on a landscape with public and private ownership: who pays for protection? Environ Manag. 2010;45(2):296-310.

17. Lehmann, P., Using a policy mix for pollution control: a review of economic literature. 2008, UFZ-Diskussionspapiere.

18. Cohen, M.A., Monitoring and enforcement of environmental policy. Available at SSRN 120108, 1998.

19. Russell CS. Monitoring and enforcement. Public policies for environmental protection. 1990;232(251):34-45.

20. Gray WB, Shimshack JP. The effectiveness of environmental monitoring and enforcement: a review of the empirical evidence. Rev Environ Econ Policy. 2011;5(1):3-24.

21. Kibler KM, Skaugset A, Ganio LM, Huso MM. Effect of contemporary forest harvesting practices on headwater stream temperatures: initial response of the Hinkle Creek catchment, Pacific Northwest. USA Forest Ecology and Management. 2013;310: 680-91.

22. Groom JD, Dent L, Madsen LJ, Fleuret J. Response of western Oregon (USA) stream temperatures to contemporary forest management. For Ecol Manag. 2011;262(8):1618-29.

23. Kolstad, C.D., Environmental economics. Second ed. 2011: Oxford University Press.

24. Croke J, Hairsine P. Sediment delivery in managed forests: a review. Environ Rev. 2006;14(1):59-87.

25. Lankoski J, Ollikainen M. Agri-environmental externalities: a framework for designing targeted policies. Eur Rev Agric Econ. 2003;30(1):51-75.

26. Shortle JS, Horan RD. The economics of nonpoint pollution control. J Econ Surv. 2001;15(3):255-89.

27. Liu Y, Goodrick S, Achtemeier G, Jackson WA, Qu JJ, Wang W. Smoke incursions into urban areas: simulation of a Georgia prescribed burn. Int J Wildland Fire. 2009;18(3):336- 48.

28. Newton M, Ice G. Regulating riparian forests for aquatic productivity in the Pacific Northwest, USA: addressing a paradox. Environ Sci Pollut Res. 2016;23(2):1149-57.

29. Dennis, R.A., E. Meijaard, R. Nasi, and L. Gustafsson, Biodiversity conservation in Southeast Asian timber concessions: a critical evaluation of policy mechanisms and guidelines. 2008 .

30. Rametsteiner E, Simula M. Forest certification - an instrument to promote sustainable forest management? J Environ Manag. 2003;67(1):87-98.

31. McComb WC, McGrath MT, Spies TA, Vesely D. Models for mapping potential habitat at landscape scales: an example using northern spotted owls. For Sci. 2002;48(2):203-16.

32. Schirpke U, Tasser E, Tappeiner U. Predicting scenic beauty of mountain regions. Landsc Urban Plan. 2013;111:1-12.

33. Ice G. History of innovative best management practice development and its role in addressing water quality limited waterbodies. J Environ Eng. 2004;130(6):684-9.

34. Aust WM, Blinn CR. Forestry best management practices for timber harvesting and site preparation in the eastern United States: an overview of water quality and productivity research during the past 20 years (1982-2002). Water, Air and Soil Pollution: Focus. 2004;4(1):5-36. 
35. Ice GG, Schilling E, Vowell J. Trends for forestry best management practices implementation. J For. 2010;108(6):267-73.

36. Karsenty A, Drigo IG, Piketty M-G, Singer B. Regulating industrial forest concessions in Central Africa and South America. For Ecol Manag. 2008;256(7):1498-508.

37. Gray, J.A., Forest concession policies and revenue systems: country experience and policy changes for sustainable tropical forestry. Vol. 522. 2002: World Bank Publications.

38. Boscolo, M. and J.R. Vincent, Promoting better logging practices in tropical forests: a simulation analysis of alternative regulations. Land Economics, 2000: p. 1-14.

39. Boston K, Bettinger P. An economic and landscape evaluation of the green-up rules for California, Oregon, and Washington (USA). Forest Policy Econ. 2006;8(3):251-66.

40. Jaffe AB, Newell RG, Stavins RN. Environmental policy and technological change. Environmental \& Resource Economics. 2002;22(1-2):41-69.

41. Requate T. Dynamic incentives by environmental policy instruments - a survey. Ecol Econ. 2005;54(2-3):175-95.

42. Becker GS. Crime and punishment: an economic approach. J Polit Econ. 1968:169-217.

43. Malik AS. Permanent versus interim regulations: a game-theoretic analysis. J Environ Econ Manag. 1991;21(2):127-39.

44. Malik AS. Enforcement costs and the choice of policy instruments for controlling pollution. Econ Inq. 1992;30(4):714.

45. Amacher GS, Koskela E, Ollikainen M. Royalty reform and illegal reporting of harvest volumes under alternative penalty schemes. Environ Resour Econ. 2007;38(2):189-211.

46. Amacher GS, Ollikainen M, Koskela E. Corruption and forest concessions. J Environ Econ Manag. 2012;63(1):92-104.

47. Kuusela, O.-P. and G.S. Amacher, Changing political regimes and tropical deforestation. environmental and resource economics, 2015: p. 1-19.

48. Wunder S. The efficiency of payments for environmental services in tropical conservation. Conserv Biol. 2007;21(1):48-58.

49. Engel S, Pagiola S, Wunder S. Designing payments for the environmental services in theory and practice: an overview of the issues. Ecol Econ. 2008;65:663-74.

50. Bulte EH, Lipper L, Stringer R, Zilberman D. Payments for ecosystem services and poverty reduction: concepts, issues, and empirical perspectives. Environ Dev Econ. 2008;13:245-54.

51. Zilberman D, Lipper L, McCarthy N. When could payments for environmental services benefit the poor? Environ Dev Econ. 2008;13:1-24.

52. Alix-Garcia J, de Janvry A, Sadoulet E. The role of deforestation risk and calibrated compensation in designing payments for environmental services. Environ Dev Econ. 2008;13:375-94.

53. Alix-Garcia J, Wolff H. Payments for ecosystem services from forests. Ann Rev Resour Econ. 2014;5.

54. Blackman A. Evaluating forest conservation policies in developing countries using remote sensing data: an introduction and practical guide. Forest Policy Econ. 2013;34:1-16.

55. Greiner R, Young M, McDonald A, Brooks M. Incentive instruments for the sustainable use of marine resources. Ocean \& Coastal Management. 2000;43(1):29-50.

56. Mathis ML, Baker PB. Assurance bonds: a tool for managing environmental costs in aquaculture. Aquaculture Economics \& Management. 2002;6(1-2):1-17.

57. Parry IW, Bento AM. Tax deductions, environmental policy, and the "double dividend" hypothesis. J Environ Econ Manag. 2000;39(1):67-96.

58. Boyd, J., Financial responsibility for environmental obligations: are bonding and assurance rules fulfilling their promise? Vol. 20. 2002: Emerald Group Publishing Limited.
59. Sullivan J, Amacher GS. Private and social costs of surface mine reforestation performance criteria. Environ Manag. 2010;45(2): $311-9$.

60. Coria J, Sterner T. Natural resource management: challenges and policy options. AnnuRevResourEcon. 2011;3(1):203-30.

61. Sullivan J, Amacher GS. The social costs of mineland restoration. Land Econ. 2009;85(4):712-26.

62. Gerard D. The law and economics of reclamation bonds. Resources policy. 2000;26(4):189-97.

63. Gerard D, Wilson EJ. Environmental bonds and the challenge of longterm carbon sequestration. J Environ Manag. 2009;90(2):1097-105.

64. Davis, L., Modernizing bonding requirements for natural gas producers. The Hamilton Project, Brookings Institution, Washington, DC, 2012.

65. Davis, L.W., Bonding requirements for US natural gas producers. Review of environmental economics and policy, 2015: p. reu015.

66. Bohm, P., Deposit-refund systems: theory and applications to environmental, conservation, and consumer policy. 1981, Resources for the Future, Inc., Washington, DC (United States); Johns Hopkins Univ. Press, Baltimore, MD (United States).

67. Becker, G.S. and G.J. Stigler, Law enforcement, malfeasance, and compensation of enforcers. The Journal of Legal Studies, 1974: p. $1-18$.

68. Perrings C. Environmental bonds and environmental research in innovative activities. Ecol Econ. 1989;1(1):95-110.

69. Costanza R, Perrings C. A flexible assurance bonding system for improved environmental management. Ecol Econ. 1990;2(1):57-75.

70. Shogren JF, Herriges JA, Govindasamy R. Limits to environmental bonds. Ecol Econ. 1993;8(2):109-33.

71. Leruth, L., R. Paris, and I. Ruzicka, The complier pays principle: the limits of fiscal approaches toward sustainable forest management. IMF Staff Papers, 2001: p. 397-423.

72. Fullerton $\mathrm{D}, \mathrm{Wu} \mathrm{W}$. Policies for green design. J Environ Econ Manag. 1998;36(2):131-48.

73. Fullerton D, Wolverton A. The two-part instrument in a secondbest world. J Public Econ. 2005;89(9):1961-75.

74. Palmer K, Walls M. Optimal policies for solid waste disposal taxes, subsidies, and standards. J Public Econ. 1997;65(2):193-205.

75. Fullerton D, Kinnaman TC. Garbage, recycling, and illicit burning or dumping. J Environ Econ Manag. 1995;29(1):78-91.

76. Dana DA, Wiseman HJ. Market approach to regulating the energy revolution: assurance bonds, insurance, and the certain and uncertain risks of hydraulic fracturing. $A$ Iowa L Rev. 2013;99:1523.

77. Van Kooten GC, Binkley CS, Delcourt G. Effect of carbon taxes and subsidies on optimal forest rotation age and supply of carbon services. Am J Agric Econ. 1995;77(2):365-74.

78. Cristan R, Aust WM, Bolding MC, Barrett SM, Munsell JF, Schilling E. Effectiveness of forestry best management practices in the United States: literature review. For Ecol Manag. 2016;360: 133-51.

79. Groom, J.D., L. Dent, and L.J. Madsen, Stream temperature change detection for state and private forests in the Oregon Coast Range. Water Resources Research, 2011. 47(1).

80. Richardson JS, Naiman RJ, Bisson PA. How did fixed-width buffers become standard practice for protecting freshwaters and their riparian areas from forest harvest practices? Freshwater Science. 2012;31(1):232-8.

81. Lee P, Smyth C, Boutin S. Quantitative review of riparian buffer width guidelines from Canada and the United States. J Environ Manag. 2004;70(2):165-80.

82. Naylor BJ, Mackereth RW, Kreutzweiser DP, Sibley PK. Merging END concepts with protection of fish habitat and water quality in new direction for riparian forests in Ontario: a case study of science guiding policy and practice. Freshwater Science. 2012;31(1):248-57. 
83. Siry JP, Cubbage FW, Ahmed MR. Sustainable forest management: global trends and opportunities. Forest Policy Econ. 2005;7(4):551-61.

84. Boltz F, Holmes TP, Carter DR. Economic and environmental impacts of conventional and reduced-impact logging in tropical South America: a comparative review. Forest Policy Econ. 2003;5(1):69-81.

85. Ezzine de Blas D, Pérez MR. Prospects for reduced impact logging in central African logging concessions. For Ecol Manag. 2008;256(7):1509-16.

86. Putz FE, Sist P, Fredericksen T, Dykstra D. Reduced-impact logging: challenges and opportunities. For Ecol Manag. 2008;256(7):1427-33.

87. Holmes TP, Blate GM, Zweede JC, Pereira Jr R, Barreto P, Boltz $F$, Bauch R. Financial and ecological indicators of reduced impact logging performance in the eastern Amazon. For Ecol Manag. 2002;163(1):93-110.

88. Medjibe VP, Putz FE. Cost comparisons of reduced-impact and conventional logging in the tropics. J For Econ. 2012;18(3):24256. This paper compares the results from 11 case studies that have analyzed the costs and benefits for harvesters of adopting RIL techniques. The results vary greatly between the different case studies, some showing net benefits whereas others net costs. This paper organizes the case studies based on their methods and definitions to make more meaningful comparisons between their results and to understand the causes for the discrepancies.

89. Macpherson AJ, Carter DR, Schulze MD, Vidal E, Lentini MW. The sustainability of timber production from Eastern Amazonian forests. Land Use Policy. 2012;29(2):339-50.

90. Paris, R., I. Ruzicka, and H. Speechly, Performance guarantee bonds for commercial management of natural forests-early experience from the Philippines. The Commonwealth Forestry Review, 1994: p. 106-112.

91. Merry FD, Amacher GS. Forest taxes, timber concessions, and policy choices in the Amazon. J Sustain For. 2005;20(2):15-44.

92. Karsenty A. Forest taxation regime for tropical forests: lessons from Central Africa. Int For Rev. 2010;12(2):121-9.

93. Macpherson AJ, Carter DR, Lentini MW, Schulze MD. Following the rules: Brazilian logging concessions under imperfect enforcement and royalties. Land Econ. 2010;86(3):493-513. This study is the most recent attempt to assess the effectiveness of performance bonds in weak enforcement environments together with other policy instruments such as renewability audits and ad valorem and revenue-based royalties. Using a simulation study, they find that performance bonds have advantages over other instruments, but the participation constraint can hinder their effectiveness.

94. Anderson, R., Incentive-based policies for environmental management in developing countries. Resources for the Future Issue Brief, 2002. 2(07).

95. Ruzicka I. Taxation of tropical forests: search for generalizations after half a century of trying 1. Int For Rev. 2010;12(2):181-6.

96. Nasi R, Putz FE, Pacheco P, Wunder S, Anta S. Sustainable forest management and carbon in tropical Latin America: the case for REDD. Forests. 2011;2(1):200-17.

97. Hyde, W.F., The global economics of forestry. 2012: Routledge.

98. Dombeck MP, Williams JE, Wood CA. Wildfire policy and public lands: integrating scientific understanding with social concerns across landscapes. Conserv Biol. 2004;18(4):883-9.

99. NIFC, Wildland fire statistics. National Interagency Fire Center. Boise, ID. Available from: http://www.nifc.gov/fireInfo/fireInfo statistics.html, 2014.

100. Everett Y, Fuller M. Fire safe councils in the interface. Soc Nat Resour. 2011;24(4):319-33.

101. Fischer AP, Charnley S. Risk and cooperation: managing hazardous fuel in mixed ownership landscapes. Environ Manag. 2012;49(6):1192-207.
102. Butry D, Donovan G. Protect thy neighbor: investigating the spatial externalities of community wildfire hazard mitigation. For Sci. 2008;54(4):417-28.

103. Shafran AP. Risk externalities and the problem of wildfire risk. $\mathrm{J}$ Urban Econ. 2008;64(2):488-95.

104. Busby GM, Albers HJ, Montgomery CA. Wildfire risk Management in a landscape with fragmented ownership and spatial interactions. Land Econ. 2012;88(3):496-517. Fragmentation of land ownership and the growing number of households living in the wildland-urban interface bring additional challenges to the mitigation of wildfire risks in the landscape level. This paper models fuel treatment decisions across a range of land-ownership patterns with spatially correlated fire risk and strategic behavior. They find that investments to fuel treatment depend on the level of ownership fragmentation and on the nature of expected damages on forest values.

105. Busby G, Amacher GS, Haight RG. The social costs of homeowner decisions in fire-prone communities: information, insurance, and amenities. Ecol Econ. 2013;92:104-13.

106. Yoder J. Playing with fire: endogenous risk in resource management. Am J Agric Econ. 2004;86(4):933-48.

107. Monroe MC, Nelson KC. The value of assessing public perceptions: wildland fire and defensible space. Appl Environ Educ Commun. 2004;3(2):109-17.

108. Brenkert-Smith H, Champ PA, Flores N. Insights into wildfire mitigation decisions among wildland-urban interface residents. Soc Nat Resour. 2006;19(8):759-68.

109. Amacher GS, Malik AS, Haight RG. Not getting burned: the importance of fire prevention in forest management. Land Econ. 2005;81(2):284-302.

110. Zhang DW, Flick WA. Sticks, carrots, and reforestation investment. Land Econ. 2001;77(3):443-56.

111. Reed WJ. The effects of the risk of fire on the optimal rotation of a Forest. J Environ Econ Manag. 1984;11(2):180-90.

112. Reed WJ, Errico D. Techniques for assessing the effects of Pest hazards on long-run timber supply. Canadian Journal of Forest Research-Revue Canadienne De Recherche Forestiere. 1987;17(11):1455-65.

113. Reed WJ, Apaloo J. Evaluating the effects of risk on the economics of juvenile spacing and commercial thinning. Canadian Journal of Forest Research-Revue Canadienne De Recherche Forestiere. 1991;21(9):1390-400.

114. Yin RS, Newman DH. The effect of catastrophic risk on forest investment decisions. J Environ Econ Manag. 1996;31(2):186-97.

115. Englin J, Boxall P, Hauer G. An empirical examination of optimal rotations in a multiple-use forest in the presence of fire risk. J Agric Resour Econ. 2000;25(1):14-27.

116. Goodnow R, Sullivan J, Amacher GS. Ice damage and forest stand management. J For Econ. 2008;14(4):268-88.

117. Lal R. Forest soils and carbon sequestration. For Ecol Manag. 2005;220(1):242-58.

118. Sohngen B, Mendelsohn R. An optimal control model of forest carbon sequestration. Am J Agric Econ. 2003;85(2):448-57.

119. Van Kooten, G.C. and B. Sohngen, Economics of forest ecosystem carbon sinks: a review. 2007.

120. Pan Y, Birdsey RA, Fang J, Houghton R, Kauppi PE, Kurz WA, Phillips OL, Shvidenko A, Lewis SL, Canadell JG. A large and persistent carbon sink in the world's forests. Science. 2011;333(6045): 988-93.

121. Lintunen, J. and Uusivuori J., On the economics of forest carbon: renewable and carbon neutral but not emission free. 2014.

122. Mason CF, Plantinga AJ. The additionality problem with offsets: optimal contracts for carbon sequestration in forests. J Environ Econ Manag. 2013;66(1):1-14. 